\title{
Project Approach in Science Learning Based on Multisensory-Ecology for Children 4-5 Years old in the Era of Industrial Revolution 4.0
}

\author{
Yaswinda \\ Early childhood education department \\ Universitas Negeri Padang, Indonesia \\ yaswinda@fip.unp.ac.id
}

\author{
Yulsyofriend \\ Early childhood education department \\ Universitas Negeri Padang, Indonesia \\ yulsyofriend@fip.unp.ac.id
}

\begin{abstract}
Project approach is one approach that is appropriate to facilitating children's learning in the Era of industrial revolution 4.0. Project approach can help children to develop cognitive skills. This study aims to find the effect of Project Approach in Science Learning Based on Multisensory-Ecology for Children 4-5 Years old and to describe the influence of Project Approach in Science Learning Based on Multisensory-Ecology for Children 4-5 Years old. The study was conducted at Aisyiyah Busthanul Athfal 86, East Jakarta. The data obtained were processed using mixed method approach, qualitative data using $t$ test, while the qualitative data using Miles and Huberman analysis. The results of the study can be concluded that indicate that there is an increase in cognitive skills of children 4-5 years old after the implementation of project approach in science learning based on multisensory-ecology. The recommendation of this research is that if kindergarten teacher want to increase cognitive skills of child aged 4-5 years then project approach in science learning based on multisensory-ecology this can become a choice in the Era of Industrial Revolution 4.0.
\end{abstract}

Keywords: project approach, science learning based on multisensory-ecology, children

\section{INTRODUCTION}

One of the principles learned in kindergarten is learning by play. But the reality of playing time kindergarten children has been reduced. Kids spend a lot of time to learning reading, writing and counting rather than learning through play and exploration, exercise and use of imagination [1]. Though exploration is the first step kindergarten in the face of the new situation. Child observes with all the senses to classify, predict, and communicate, so that they can find another viewpoint [2].

Kindergarten curriculum includes not only the activities of children socially and emotionally, but also reading, writing, mathematics, art and science by considering Desire child's learning. This is the underlying rationale for bridging this problem, we need a science learning that can provide science experiences for children that focuses on developing social-emotional, physical, and cognitive [3]. During this early childhood education is focused on the development of social, emotional, and physical and language skills and basic arithmetic. Giving science a rare experience. Though investigations into the phenomenon of child science not only to build the experience base for learning science then, but also for the development of cognitive skills .

As a term, science is a study dealing with facts or truths systematically arranged and showing the operation of general law [4]. Science can also be interpreted as a way to try to find the essence of things, attitudes and skills that allow individuals to solve problems they encounter in everyday life [5]. Learning science in children an early age can be defined as things that stimulate children to raise the curiosity, interest and problem solving, which raises the thoughts and deeds such as observing, thinking, and linking between concepts or events [6]. Science is about trying to understand the world he saw the man, animals, plants, and other objects in the environment by experimenting and report the findings [7]. Science for children focuses on how children interact with the world around them [8]. But in reality, the kindergarten teacher is using a lecture and demonstration in science learning children. In the method the teacher demonstration did not involve children doing science experiments, children only as a spectator for comment [9]. In fact, science learning can also be provided with project learning [10]. According to Schiro, the project approach is a learning that applies child-centered learning ideology. In this case, teachers help children learn and enable children to move from personal, concrete, and physical experiences to learning abstract, verbal and intellectual understanding. In this approach the teacher creates an environment to support the learning and observation of children. The project method is a way of providing learning experiences by giving children problems or daily problems that must be solved in groups. The benefits of this method is to improve the skills already owned and provide opportunities for children to realize the power of creativity. Project approach is one approach that is appropriate to facilitating children's learning in the Era of industrial revolution 4.0.

Though learning in kindergarten must consider the time spent on the child as an active learner. Children can use all their senses to discover new things. This means that children need support to learn to use a lot of sense. Sensory is the process of detecting the presence of stimuli from the outside environment through the senses. In humans there are five sensory systems, namely: the visual system, auditory, somatosensory, olfactory, and gustatory [11]. Multisensory experience of the child is an early stage of learning concrete and developmentally appropriate. Multisensory experience of children with objects and people in the environment is the main thing to build a child's understanding of their world [12]. 
Ecology is the study of all the elements of the environment, both living (biotic) and nonliving (abiotic), and the relationship between these elements [7]. Ecology is also defined as the study of living organisms in relation to their environment and each other [8]. Ecology shows that living things are connected to each other, disorders that arise from this relationship will bring consequences that often undermine such populasi growing human and technological advances have damaged the natural system that never existed before [13]. Ecological education is recommended in order to be implemented in all levels of education [14].

Vygotsky believed that the intellectual development of children affected by the social context rather than an individual experience. The theory puts much emphasis on effective social interaction. Vygotsky believed mental development, language, and social supported and enhanced through interaction with others. The learning process can only occur when children interact and cooperate with the surrounding environment [3].

Science insructional model based on multisensory-ecology is learning that prioritizes process skills and content of science through experience multisensory (activities that involve the senses of sight, hearing, feeling, smelling and tasting) and of the importance of human interaction with the surrounding environment (between humans and living beings other and the objects are not alive) in an integrated learning with the aim of improving cognitive, social emotional and physical with five characteristics and the five principles of learning that are made in a draft conceptual model. Based on the things that have been described previously, it needs a learning model that can be one of the guidelines for kindergarten teachers to develop aspects of cognitive skills and social emotional learning that emphasizes science involvement and interaction with the environment. But this article is focused on discussion on improving cognitive skills of Aisyiyah kindergarten. Therefore, the development of science-based development model of multisensory-ecology needs to be done to improve children's cognitive group A Aisyiyah kindergarten. This study aims to find the effect of Project Approach in science learning based on multisensoryecology for children 4-5 years old and to describe the influence of project approach in science learning based on multisensory-ecology for children 4-5 years old.

\section{METHOD}

The study was conducted from March 16 to July 2016 at Aisyiyah Busthanul Athfal 86 kindergarten, East Jakarta. The method used in this study is a research and development, he combination of the model Borg and Gall [15], with Gall, Gall, and Borg, [16]. The data obtained were processed using mixed method approach, qualitative data using $\mathrm{t}$ test, while the qualitative data using Miles and Huberman analysis.

\section{RESULT}

In the research, the children around the world than they make a project by individual or gruop. Example, they made a car from botle and paper; a handycraf from seeds; toy ttaffis signs; and trash can.

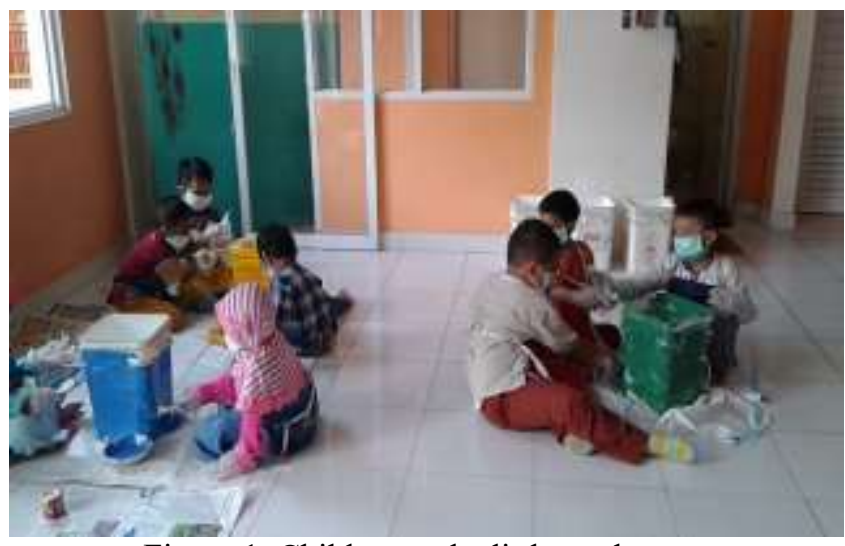

Figure 1. Children make little trash can

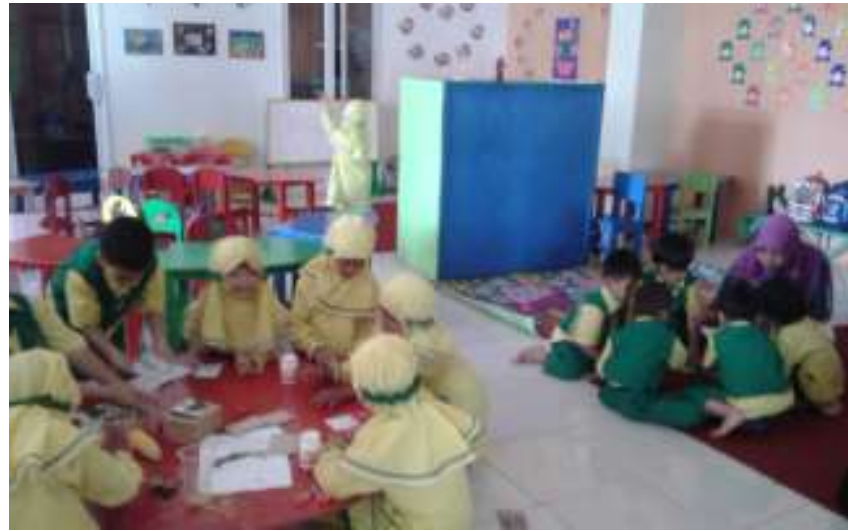

Figure 2. Children make handycraf from sed

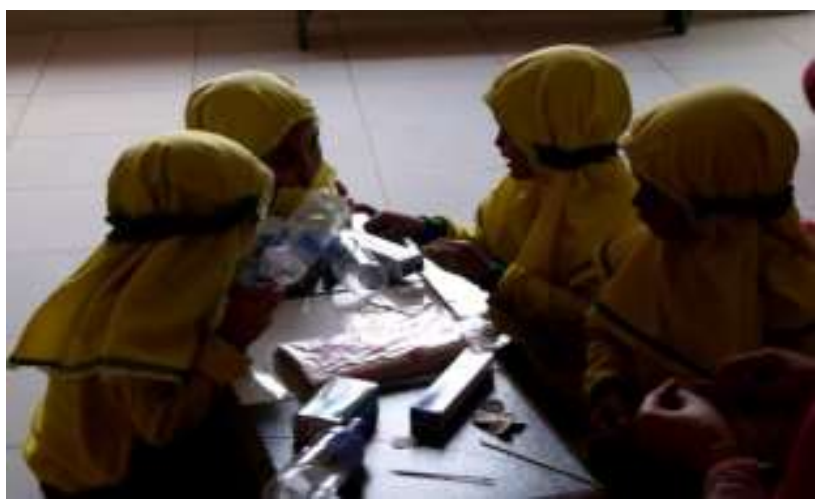

Figure 3. Chihdren make car's

Developing themes referenced in the development of learning materials based on the content of science is taught to children, namely: (1) Content of Physics, which is associated with magnetism, measurement/conversion, floating and sinking, evaporation, images and sound; (2) Content Biology, which is associated with the growth of plants, all kinds of leaves, assorted fruit, all kinds of flowers, and a variety of seeds; (3) Content Earth and the Universe in touch with rainbow, sky, water, soil, and sun; and (4) Content environment, dealing with environmental hygiene, floods, recycling activities such as making special trash cans, made ornament refrigerator from seed, making flowers from glass packaging, and make a toy vehicle from scrap materials. 
The results of the evaluation of the cognitive skills of children presented in figure below.

\section{Score of Children Cognitive Skills Assessment}

100

\section{$\begin{array}{lllllllllllllll}1 & 2 & 3 & 4 & 5 & 6 & 7 & 8 & 9 & 10 & 11 & 12 & 13 & 14 & 15\end{array}$ Before formative evaluation \\ After formative evaluation I}

Figure 4. Average Score Cognitive Skills 15 Children Before and After Test Formative Large Group.

Furthermore, the t-test performed on the data before and after the child's ability formative evaluation of the 15 major groups of kindergarten children group A. Acquisition value t count child's cognitive ability is 9.42 . Value t-test table in one direction with a confidence level of $\alpha=95 \%$ with a degree of freedom $(\mathrm{df}=\mathrm{n}-1)$ is 1.76 . Because the $t$-count value is greater than than $t$-table, the researchers reject the null hypothesis means that the working hypothesis is accepted. This means that statistically there is an increase in cognitive abilities after evaluation formative large groups.

\section{DISCUSSION}

Piaget's theory explains how children think, understand and learn as Piaget believes intelligence is a cognitive process that the child obtained through concentration. Through the concentration of activities, child observations of objects directly in the environment, in this research activity is evident in the implementation of large groups of formative evaluation as seen in the water play activities, walk to the park and trips to the car lot. The idea of Piaget's theory can be implied by: (1) provide opportunities for children construct their own knowledge; (2) perform physical and mental activities for knowledge formulated through the active involvement of children studied objects in the environment; (3) provide an interesting and meaningful experiences; (4) to active learning to help children in problem-solving activities; and (5) provide opportunities for children to play fantasy by providing tools and materials required. In the project approach in science learning based on multisensoryecology, that children are often given the opportunity to construct their own knowledge through activities such activity ekspolarasi clean environment, water play, activity rainbow, playing in the garden, and play at the car lot.

Reference [17], Children need to learn the principle of repetition. The better trained the use of memory, the more connections made in the brain and the easier we remember things. In this model the ability of the child's language is the ability to communicate what is known about a concept or scheme either newly acquired or which is a process equlibrasi deiberikan stout opportunity in the loop appearance is done repeatedly, and so are the skills fine motor also experience an increase in the repetition of activities plumb and create a circle. This is evidenced by the results of observations assesemen cognitive abilities of children.

According of French, children are motivated to explore the world around them [18]. In the research, the children around the wold than they make a project by indufidual or group. Example, they made a car from botle and paper; a handycraf from seeds; toy ttaffis signs; and little trash can. Science and Literacy provides a systematic instructional framework, a standards-based curriculum, and high quality teacher resources [19]. In research, the children are reading, writing and talking about their science projects. This is similar to research on science learning can also be provided with project learning [10]. According to Schiro, the project approach is a learning that applies child-centered learning ideology. In this case, teachers help children learn and enable children to move from personal, concrete, and physical experiences to learning abstract, verbal and intellectual understanding. In this approach the teacher creates an environment to support the learning and observation of children. The project method is a way of providing learning experiences by giving children problems or daily problems that must be solved in groups. The benefits of this method is to improve the skills already owned and provide opportunities for children to realize the power of creativity.

Children need to urge teachers to gain experience science through play and interaction [20]. Based on the research findings obtained as a result of formative test, there are three main things that need to be considered by the teacher to apply science learning based on successful multisensory-ecology, namely: preparation of study room, preparation of instructional media, guiding children in learning, and assessment of children ability. Providing opportunities for children to experiment meant to encourage children dare to try. For example in water play activities, the stage of the child builds his own concept of knowledge through project learning as follows: (1) teachers provide opportunities for children to explore with water and equipment that support measurement / conversion activities; (2) the child interacts with their's friends about water conversion or measurement; (3) the teacher explains the concept of measurement through demonstration; and (4) furthermore the teacher gives the child a chance to build their own concept. The results of this study support Yaswinda's research (2016) that the characteristics of multisensory-ecological science learning can be done using the project method

The limitations of this study are as follows: (1) object of research that one kindergarten that is Aisyiyah Busthanul Athfal 86 kindergarten with using learning resource which is around Aisyiyah Busthanul Athfal 86 kindergarten that is ball field, city park and car sale place; (2) research subjects in this case children who participated in large classes only amounted to 18 children due to the number of children aged 4-5 years in Aisyiyah Busthanul Athfal 86 kindergarten amounted to 27 children, nine children were included in the small group formative test so that children can be included in Formative test of a large group of 18 children; and (3) learning science based 
on ecology is still limited in scope so that further research is needed which provides a deeper base on ecological education.

\section{CONCLUSION}

The results of the study can be concluded that indicate that there is an increase in cognitive skills of children 4-5 years old after the implementation of project approach in science learning based on multisensoryecology. The recommendation of this research is that if kindergarten teacher want to increase cognitive skills of child aged 4-5 years then project approach in science learning based on multisensory-ecology this can become a choice. Further studies with more attention to education intergratif, by developing learning science based on multisensory-ecology to increase the aspect of religious values and moral, cognitive, social-emotional, physical, and the art of children and designing the learning science based on multisensory - ecology that provides a more meaningful emphasis on ecological education. The recommendation of this research is that if kindergarten teacher want to increase cognitive skills of child aged 4-5 years then project approach in science learning based on multisensory-ecology this can become a choice in the Era of Industrial Revolution 4.0.

In this moment I would like to thank Mrs. Prof. Dr.Yufiarti, M.Psi and Prof. Dr. Atwi Suparman, M.Sc. Financial support from the PGPAUD Universitas Negeri Padang very helpful publication of this article.

\section{REFERENCES}

[1] Miller, E. and Almon, J. Crisis in the Kindergarten, Why Children Need to Play in School. College Park: Alliance for Childhood, 2009

[2] Lind, K.K. Science in Early Childhood: Developing and Acquiring Fundamental Concepts and Skills in Early Childhood Dialogue on Science, Mathematics, and Technology Education,http://www.project2061.org/ publications/earlychild/online /experience/lind.htm,

[3] [Morrison G S. Fundamentals of Early Childhood Education (ECD). Konsep PAUD, Fifth edition. Jakarta: Index, 2011
[4] [Morrison G S. (2011). Fundamentals of Early Childhood Education (ECD). Fifth edition. Jakarta: Index.

[5] Charlesworth, R and Lind, K.K. (2010). Math and Science for Young Children, Sixth Edition, Wadsworth, Cengage Learning. Belmont, 2010.

[6] Brewer,J.A. Early Childhood Education, Preschool Throught Primary Grades, Sixth Edition. Boston : Pearson, 2007.

[7] Mayesky (2012). Creative Activites for Young Children, 10th Edition. Wasworth, Cengage Learning, 2012.

[8] Jackman, H.L., (2012). Early Education Curriculum, A Child Connection to The World. Fifth Edition, Wadsworth: Cencage learning, 2012.

[9] Roza, Mela Murti. (2012) Science Learning Implementation kindergarten Aisyiyah Bustanul Athal 29 Padang. PESONA PAUD Scientific Journals, PGPAUD FIP. UNP Volume 1 Number 1, 2012.

[10] Sari, Nuryadin, and Sujiono. Early Childhood Education, April 2014, Jakarta: PPS UNJ, Volume 8 Issue 1.

[11] Puspita, I, Indri, I ,. Hapsarii, Suryaratri, R.D., Psychology and Psysiology Review in Understanding Human Behavior, Bandung: PT Rosdakarya Muda, 2012.

[12] Henniger, M.L. Teaching Young Children: An Introduction, 5th Edition, Boston: Pearson, 2013

[13] [Burne, D., Ecology. Jakarta: Erlangga, 2005.

[14] Clark, K.E, (2013). Ecological Intelligence and Sustainability Education in Special Education Multicultural Education, 21.1), http: // www. Caddogap.com. p. 38

[15] Borg, WR and Gall, MD. Educational Research. New York: Longman. 1983

[16] Gall, M D., Gall, J P, and Borg. Walter R. Educational Research, 8th Edition. Boston: Pearson Edu, 2007.

[17] Buzan, Tony. The Ultimate Book of Mind Map. Harper Collins, 2005

[18] French, L. (2004). Science as the Center of a Coherent, Integrated Early Childhood Curriculum. Early Childhood Research Quarterly, 19(1), 138

[19] Trundle, KC. (2009) SCL22-0429A · 07/09 Teaching Science during the Early Chldhood Years, (3) 1.

[20] NSTA position statement (2014): early chidhood science education on Science and Children, 517 (Mar, h 2) http: //www.nsta.org.

[21] Yaswinda, Yaswinda. Science Learning Model Based on Multisensory-Ecology in Early Childhood Education: A Conceptual Model. 3rd International Conference on Early Childhood Education (ICECE 2016). 2016. Atlantis Press 